\title{
Avena Besseri Grisebach i formy pokrewne (Avena Besseri Grisebach and the nearest relations)
}

\author{
Napisał \\ Marian Koczwara
}

Owies odkryty przez Wilibalda Bessera na górach Kulikowskich w okolicy Krzemieńca ${ }^{1}$, określony przez niego jako Avena sempervirens Host ? (I) jako taki wymieniony ogólnie przez E. Eichwalda dla Wctynia i Podola (2) a przez A. Andrzejowskiego podany z nad Bohu, Smotryeza i Zbrucza pod nazwą Elicotrichum sempervirens Besser (3), wszedł do szerszej literatury naukowej we Flora rossica C. F. Ledeboura (4) jako Avena Besseri Grisebach.

Ledebour odróżniał naogół trafnie owies ten od zbliżonego doń gatunku Avena desertorum Lessing, zami€szkującego obszary naddnieprzańskie i nadwołżańskie oraz Azję i Syberję. Podobnie uważał go za odrębny gatunek A. Rehman, który po odkryciu w Miodoborach, wprowadził go do nowszej literatury botanieznej polskiej również pod nazwa Avena Besseri (5).

Mimo to nastęny po Ledebourze autor flory rosyjskiej, J. Schmalhausen (6) uznał owies, odkryty przez Bessera za identyezny z owsem Lessinga i od tego czasu (1897) owies ten widnieje w pracach botaników rosyjjkich (Kryłow, Fedezenko, Komarow ii.) polskich (Paczoski, Raciborski ii.), niemieckich (Ascherson, Graebner, Hegi ii.) oraz czeskich (Podpěra, Domin ii.) jako Avena desertorum Lessing ${ }^{2}$. Przy okazji przeglądania zielników Uniwersytetu Lwowskifgo zwróciłem, w swoim czasie, uwagę na różnice, zachodzące między

1 Co Besser rozumiał pod górami Kulikowskiemi niewiadomo. Pod Kulikowem znajduje się tylko jedna góra: Sokola czyli Łysa, na której owies ten dzisiaj nie rośnie. Natomiast trafia się jeszcze dzisiaj na leżącej bliżej Krzemieńca górze Maślatyn i na skraju jaru krzemienieckiego.

2 Podpěra odkrył w r. 1902 w Czechach a w r. 1912 na Morawach owies, który nazwal pierwotnie Avenastrum basalticum. Podp. względnie Avenastrum desertorum Lessing. v. basalticum. Ostatecznie jednak nazwe te skasował wprowadzająe w r. 1928 termin: Avenastrum desertorum Podp. (8). 
owsem Lessinga a owsem Bessera i nadałem temu drugiemu, prowizorycznie, wartość odmiany, głównie na podstawie pewnych cech ilościowych (7).

Obecnie poddalem bliższym badaniom tak owies Lessinga (Bajgansg, pow. Bałagansk, okr. Irkucki, oznaczał D. I. Litwinow) jak okazy owsa Bessera z Podola (Ostapie w Miodoborach, oznaczal A. Rehman, Ostrowiec pod Horodenką, ozn. M. Raciborski ii.) oraz z Czech (Ranne k. Loun, oznaczał K. Domin).

Porównanie okazów z tych różnych okolic wykazuje między nimi niewątpliwie znaczne podobieństwo.

Są to wszystko trawy trwałe, gęstokepkowe, otulone w dole resztkami starych pochw liściowych, o źdźbłach gładkich, tylko pod i w obrębie gałązek wiechy kwiatowej szorstkich, pochwach liściowych owłosionych, języczku pędów płonych wydłużonym (3-6 mm dł.), pędów kwiatonośnych krótszym (I. 5-3 mm dł.), liściach szorstkich, na wewnętrznej tj. dolnej powierzchni owłosionych, szczeciniastych, 7 nerwowych. Kłoski wiechy zwykle 3 kwiatowe, przy ezym kwiat najwyższy płony, szypułki kwiatów owłosione, plewy dọlne 1-no, górne 3-nerwowe, zaostrzone, szorstkie zwłaszcza na nerwachbokiem słabo orzęsione, plewki dolne niewyraźnie 7 nerwowe, opa, trzone ością obłą, na szczycie ząbkowane, szorstkie, brzegiem słabo orzęsione, górne błoniaste, na szczycie 2 ząbkowane, brzegiem silnie orzęsione.

Mimo tych podobieństw wyróżnia się jednak owies Lessinga od owsa Bessera kilku wyraźnymi cechami jakościowymi, a to przede wszystkim w wykształceniu i budowie liścia oraz języczka liściowego

Owies Lessinga ma liście grubsze i sztywniejsze, złożone w pól, z zewnątrz nieżeberkowane, na końcach niezwinięte, prawie nagie, szorstkie od ząbkowatych względnie haczykowatych wyrostków komórek skórki, w zasadzie nie dorastające wysokości źdźbel. kwiatonośnych. Na przekroju poprzecznym wykazują liście kształt ditery V, a pod skórką jednolity pierścień sklerenchymy. Pochwy liściowe częściowo szorstko ząbkowane, częściowo owłosionc.

Języczek liściowy zrazu zaokrąglony pot€m podzielony, na powierzchni a zwłaszeza brzegiem, gęsto frendzlowato orzęsiony Plewy opatrzone na szczycie kępką włosków, plewka dołna na końcu wyraźnie 2 ząbkowana, szypułki kwiatowe krótsze (4-5m-m),

Owies Bessera ma liście cieńsze, włosowate dochcdzące długości źdźbeł kwiatonośnych a czas€m je nawet przewyższające, zwinięte do środka a na końcach skręcone luźno żeberkowane, z zewnątrz z rzadka owłosione, szorstkie mniej od słabo wykształco- 
nych ząbków skórki a głównie od tworzących żeberka, ułożonych rzędami po 1 lub 2, komórek skórki. Na przekroju poprzecznym wykazują liście zarys 7 -kątny od 7 żeberek, które są wytworzone przez skupienia silniej wyksztalconych komórek skórki występujących w miejscach nadległych wiązkom naczyń, pierścień sklerenchymy pod skórką nie jest zwarty a przerywany, występuje głównie pod żeberkami a brak go między nimi. Pochwy liściowe owłosione gęściej włoskami cieńszymi a dłuższymi. Języczek liściowy wyciągnięty, nagi lub prawie nagi, po bokach i na szezycie postrzepiony. Plewy na końcach bez kępki włosków, plewki dolne na szczycie niewyraźnie ząbkowane, szypułki kwiatowe dłuższe $(5-6 \mathrm{~mm})$.

Jak powyższe dane wskazują owies z Podola wyróżnia się od owsa z Syberii kilku wyraźnymi cechami morfotycznymi i anatomicznymi.

Pozwala to na restytuowanie go jako dobrego gatunku: Avena Besseri Grisebach względnie Avenastrum Besseri (Grisebach) oraz na wznowienie, z pewnymi zmianami, diagnoz wprowadzonych przez Ledeboura.

Avena desertorum Lessing (Lessing in Linnaea IX p. 208): Rhizomate fibroso foliis compressis, complicato setaceis, fere nudis, scabris, erectis, imis culmo superatis, superiorum ligula brevi, inferiorum oblonga, superficie et apice obtusiuculo dense ciliolata, panicula simpliciuscula, ramis geminis vel solitariis, spiculis $2-3$ floris $^{1}$ axi villosa, apice nuda, pedunculis $4-5 \mathrm{~mm}$ longis, glumis scabris apice. et margine ciliolatis, gluma inferiori uni- superiori tri-nervi, palea inferiori indistincte 7 nervi, margine sparsim ciliolata, scabriuscula, apice scariosa bidentata, arista teretiuscula dorso medio inserta, palea inferiori membranacea bipartita, margine valde ciliata.

Avena Bessei i Grisebach (C. F. Ledebour, Flora rossica 1863, IV,p. 415): Rhizomate fibroso, foliis convoluto capillaribus scabris extus sparsim pilosis, apice laxe contortis 7 costis adornatis, imis culmum saepe superantibus, superiorum ligula brevi, inferiorum oblonga, apice lacera, nu da aut sparsim ciliolata panicula pauciflora, ramis geminis vel solitariis, spiculis $2-3$ floris, axi villosa, apice nuda, pedunculis $5-6$ mm longis, glumis scabris, margine ciliolatis, gluma inferiori uni- superiori tri-nervi, palea inferiori indistincte 7 nervi, margine sparsim ciliolata, scabriuscula, apice scariosa, in distincte dentata, arista teretivscula, dorso medio 
inserta, palea inferiori membranacea, apice bipartita, margine valde ciliolata.

Jest rzeczą interesującą że owies z Czech i Moraw zaliczony ostatnio przez Podr ěre i Domina (8) do gatunku Avenastrum desertorum Podł era ${ }^{1}$ wykazuje cechy morfotyczne i anatomiczne, zbliżające go nie do owsa Lessinga ale właśnie do owsa Bessera: liście włosowate, skręcone na końcach, zwinięte do środka, żeberkowane, z zewnątrz owłosione, na przekroju 7 kańciaste, o skórce b€z baczykowatych wyrostków komórek skórki, o przerywanym rierścieniu sklerenchymy, języezek liściowy ferczrywany, prawie nagi.

Od okazów podolskich wyróżnia się nacgół wyższym wzrostem żdźbeł, przerastających liście a może także zatokowato wyciętymi plewami ${ }^{2}$.

Owsowi temu przysługujé zatem nazwa Avena Besseri Griseb. względnie AvenastrumBesseri (Grisebach) a ranga najwyżej słabej odmiany.

\section{II}

Owsy powyższe zamieszkują odrębne tereny, wykluczające się wzajemnie, tworzą zat $€$ gatunki zastępeze, o zasięgach przedzielonych znacznymi dysjunkejami.

Avena Besseri rośnie: w okolicy Krzemieńca $(9,10)$ na Dziewiczych skałkach i górze Maślatyn, przy ekspezyeji zachodniej, tu i tam na sarmackich piaskoweach, w towarzystwie gatunków jak: Alium strictum, Helianthemum canum. Sempervivum ruthenicum, Dracocephalum austriacum, Dianthus pseudoserotinus, Stipa capillata, St. Joannis, Trinia Henningii, Carex humilis ii.

Na Łysej koło Złoczowa występuje na wapienzu, przy ekspozyeji południowej $(11,12)$, w zespole turzycy niskiej, w towarzystwie: Carex humilis, Echium rubrum, Jurinea arachnoidea, Avena Schelliana, Scorzonera hispanica ii.

Na Podolu pokuckim wystẹuje na gipsach, zwykle przy eks r pozyeji W, NW rzadziej N i E. Tworzy tu samodzielne zesfoły o charakterystycznych gatunkach: Schivereckia podolica, Thalictrum uncinatum, Viola Joi, (Trifolium lupinaster, Polygala sibirica) a także

1 Tak brzmi nazwa według autorów ezeskich, według obowiązującego zwy czaju powinna zawieraé nazwisko poprzedniego autora, zatem: Avenastrum de. sertorum (Lessing) Podpěra.

2 Wobec zbyt małej liczby okazów nie można dokładnie ustalić, o ile są to cechy stale, 
miesza się z innymi zespołami zwlaszczá Stipetum capillatae i Caricetum humilis $(13,14,15,16)$.

Poza tym rośnie w Miodoborach (17. 18, 19),

W Czechach występuje ten owies w miejscowości Ranne k. Loun, na bazaltach, przy ekspozycji SE jako facja Caricetum humilis-Erysimum crepidifolium, w towarzystwie: Stipa pulcherrima, Avena pratensis, Astragalus austriacus, A. exscapus, Verbascum phoeniceum ii. $(16,20,21)$.

$\mathrm{Na}$ Morawach w Sibenicniku k. Mikulova rośnie na wapieniach przy ekspozycji W, jako facja Caricetum humilis-Scabiosa suaveolens, w towarzystwie: Stipa capillata, Adonis vernalis, Alsine setacea, Artemisia campestris, Astragalus austriacus, Seseli hippomarathrum, Dorycnium germanicum, Melica glauca, Euphorbia Seguieriana i.. (16, $20,21)$.

Poza tym trafia się na Kaller Heide k. Drasenhofen w Dolnej Austrii, w towarzystwie Melica ciliata, M. transilvanica, Erysimum durum, Vicia striata, Silene conica ii. (23).

Avena desertorum rośnie na kilku oderwanych stanowiskach w obszarze Wołżańsko-Kamskim i Wołżańsko-Dońskim (m. i. na wapieniach. Kursko-Orelskich) i nad średnim Dnierrem. Zasiąg zwarty sięga od Zawołża poprzez zachodnią Syberię (obszar Wierchnie Tobolski, Irtyski, Ałtajski) do Syberii wśchodni€j (obszar AngarskoSajański (Dahurja), Mongolji i centralnej Azji (Dżungar ja,Kaszgaria, obszar Tarbagatski, Prybałchaszski, Aralokapsijski, syrt Darji, Pamirsko-Ałajski i Tian szan) (29).

Występuje tu na glebach głębszych jak gliny, czarnozi€m i ziє mie kasztanowate badź na skałach wszelkiego redzaju: wapieniach, łupkach, porfirach, granitach, serł€ntynach ii. głównie rrzy €ksfozycji południowej i południowo-wschodniej, przy czym tworzy częściowo własne zespoły a częściowo w lączności z innymi gatunkami traw zwłaszeza ostnie: Stipa capillata, Stipa stenophylla, St. Lessingiana, St. dasyphylla, St. Joannis ii. lub kostrzew szczególnie: Festuca sulcata wzglęnie $F$, vallesiaca oraz innymi trawami jak Avena Schelliana, Koeleria gracilis ii.

Towarzyszą mu gatunki charakterystyczne, znane już z Podola jak: Schivereckia podolica, Thalictrum petaloideum, (Trifolium lupinaster, Allium strictum, Polygala sibirica) ${ }^{1}$ a także inne zważane ua

1 W nawiasie gatunki o mniej określonym stopniu wierności: Trifolium lupinaster trafia się po innych zespołach (np. Sesslerietum Heufleriannae), Polygala sibirica rośnie na tym obszarze wlaściwie w zespole Stipetum capillatae, który jest prawdopodobnie sukcesja po Avennetum Besseri a Allium strictum trafia sie tylko 
charakterystyczne: Hesperis aprica, Bupleurum multinervum (16) a poza tym Thalictrum foetidum, Gypsophila altissima, Dracocephalum austriacum ii. $(20,24,25,26,27)$.

Trafia się ponadto w lasach sosnowych jak np. w Bajgansku oraz w obrębie tajgi syberyjskiej, jak w Jelikinoj $(16)^{1}$.

\section{III}

Gdzie można szukać właściwej ojezyzny owsa Bessera, z której przybyl na dzisiejsze swoje stanowiska?

Według panującej opinii (ostatnio Kozłowska (15) i Pawłowski (28)) za centrum powstania owsów z podrodzaju Avenastrum Jessen. do którego należy tak Avena desertorum Lessing jak i Avena Besseri Griseb., uważa się okolice Morza śródziemnego.

Opiera się ten pogląd na występowaniu na obszarach M. śródziemnego przeważającej liczby gatunków, należących do tego podrodzaju, zbliżonych do siebie morfotycznie - jakkolwiek dających sie od siebie dobrze odróżnić - i tworzących przeważnie odrębne rasy geograficzne, względnie endemizmy.

O ile chodzi o interesujące nas tutaj formy, jako pokrewne Avent Besseri, wchodzićby mogły w rachubę sekeje: Setacaeae Rouy i Intermediae Rouy (30).

W skład pierwszej z nich wchodzą gatunki:

Avena setacea Vill.

który zamieszkuje:

Avena filifolia Lag.

który zamieszkuje:

Avena sempervirens Vill.

który zamieszkuje:

Avena montana Vill.

który zamieszkuje:

Avena decora Janka
Alpy zach. Isére, Drôme, Vaucluse, $\mathbf{W y -}$ sokie i niskie Alpy franc. Alpy nadbrzeżne.

Pireneje, SEFrancje, Dalmację, Kalabrię, Algier.

Alpy zach. (Sabaudia), Wysokie i niskie Alpy franc. Alpy nadbrzeżne.

Pireneje, Dauphine, Pireneje, W Alpy, Vaucluse, Cantal, Aveyron, Górna Loire.

Góry Siedmiogrodu i S Karpaty

na krawędzi północnej Podola, gdzie Avena Besseri nie tworzy w ogóle zespołów a oba gatunki rosną tylko na tych samych stanowiskach.

1 Niektórzy autorzy podają owies ten także z Wołynia (Horodnica k. Zwiahla), gdzie miał go zbierać Rogowicz. Paczoski uważa dane te za nieścisłe (20). danyeh.

We florze Polski podany także z Raszkowa nad Dniestrem bez bliższych 
Do drugiej z nich należy:

Avena Parlatorei Woods

który zamieszkuje:
Alpy zach. Wysokie i niskie Alpy franc. Alpy bawarskie, Tyrol, Krainę, Górną Italję, Dolną Austrię ${ }^{1}$.

Jak zestawienie obszarów zamieszkałych przez te owsy wskazuje, są to gatunki o charakterze zasadniczo górskim, przeważnie południowo-środkowo-europej̧skim (Alpy, Pireneje, Karpaty, Owernia).

Jednakże do pokrewieństwa Avena Besseri zaliczyć należy przede wszystkim najbliżej stojący gatunek: Avena desertorum Lessing. Ten zaś ma swoje nawiązania w sekcji Deserticolae Komarow (29), owsów stepowych i pustynnych, zamieszkujących przeważnie centralną Azję.

Oprócz Avena desertorum Less. należą tu:

Avenastrum Kryłowii N. Pawł., rosnący na obszarze Leny i Kolymy, Avenastrum hissaricum Rożew. rosnący na obszarze PamirskoAłajskim.

W dalszej mierze zalicza się tu sekcja Tianschanicae Komarow (29), obejmująca gatunki:

Avenastrum tianschanicum Rożew.

Tian szan

zamieszkujący:

Avenastrum Fedczenkoi Rożew.

zamieszkujący :

Avenastrum mongolicum Rożew.

zamieszkujący:

obszar Pamirsko-Altajski

Ałtaj, obszar Angarsko-Sajanski, Dahurję, Mongolję, Dżungarję, i obszar Tarbagatski.

Gatunki powyższe zajmują zatem obszary pustynno-stepowe oraz tereny górskie ale klimatycznie odmienne od środkowo-europejskich, bardziej kontynentalne, typu centralno-azjatyckiego ${ }^{2}$.

W takich terenach górskich znachodzi się czasami także Avena desertorum Less., np. w górach Zasajanskich, na Tianszanie lub Ałtaju, gdzie jak pisze Kryłów: „po stiepnym dolinam gornych rieczek zachodit do prediełow alrijskoj oblasti" $(26,16,27)$.

Podobny charakter klimatyczny, jakkolwiek w słabszym stopniu, przejawia Avena Besseri, zamieszkujący skaliste ścianki i zbocza gipsów, wapieni i wapnistych piaskoweów względnie bazaltów, w mniej kontynentalnych warunkach klimatu.

1 Niektórzy autorzy zaliczają tu także gat. Avena macrostachya z Algieru (15).

2 Poza tym do pokrewieństwa Avena desertorum Less. względnie Avena Besseri Griseb. zaliczają niektórzy autorzy: Avena aspera Munro i Avena polyneura Hook. zamiezskujące Himalaje, S Indje i Cejlon oraz Avena Junghuhni z Jawy (15, 16). 
Przy rozpatrywaniu sekeji Deserticolae Komarow i Tianschanicae Komarow uderza znaczna ilość endemizmów względnie ras: geografieznych oraz fakt, że większość gatunków występuje, w zasadzie, w granicach zasięgu Avena desertorum.

Pod tym względem zachowuje się odmiennie Avena Besseri, który stanowiska swoje posiada poza zasięgiєm Avena desertorum, na jego zachodnich peryferiach, oddzielony znacznic jszą dysjunkeją.

Jak z powyższego wynika, obok centrum śródzi€mnomorski€go, zarysowuje się drugie, środkowo-azjatyckie centrum owsów z podrodzaju Avenastrum Jess. o walorach twórczych nie mniejszych jak tamto i pewnych oznakach poważniejszego wieku: endemizmach, rasach geograficznych, oraz dysjunkejach oddzielających poszezególne gatunki.

Biorąc pod uwage momenty łączące gatunek Avena Besseri Griseb. z gatunkiem Avena desertorum Less. a to: nawiązania morfotyczne, a także w rozmieszczeniu, warunkach siedliska oraz moment społeczny, wiążący zespoły tych owsów uznać, nale ży tym samym za właściwy. związek Avena Besseri Gris. z stepowo-pustynnym obszarem Azji środkowej jako centrum twórezym a nie z środkowo-€uropejskim obszarem górskim względnie śródzic mncmcrshim.

Jeśli nawet nie byłoby to picrwotne, nie mniej rrzeto jest ta. właściwe centrum twórcze Avena Besseri Griseb.

\section{IV}

Jeśli $z$ kolei zechcemy odpowiedzieć na pytanie co do wieku, od którego liczyć nale ży pobyt owsa Bessera na obeenych terenach, to, biorąc pod uwage fakt, że owies ten wykazuje charakter gatunku zastępczego wobec owsa Lessinga, r rzy czym oddzic la go znacznie jsza dysjunkcja od niego - a zasiąg własny jest równiє ż porozrywany (Podole pokuckie, Miodobcry, krawędź rółnocna, Podole rosyjskie, Czechy, Morawy, Dolna Austria) - rrzywiązanie wyłącznie do terenów niezlodowaconych oraz obecncść rcślin charakterystycznych o pewnych morfotyeznych i geograficznych walcrach foważniє jsze go wieku, uznać można ogólnie gatın€k t€n za związany oddawna z dzisiejszym obszarem rozmiє szczenia.

Przy tym fakt, że tak zesłół Avena Besseri jak zeşół Avena desertorum zawi€rają częścicwo te same gatunki ckarakterystyczne (Schivereckia podolica, Thalictrum uncinatum względnie Th. petaloideum, (Allium strictum, Polygala sibirica, Trifolium lupinaster)), 
wskazuje na to, że izolacja owsa Bessera od owsa Lessinga nastąpiła stosunkowo dawno.

Stanowiska tych owsów oddziela od siebie język kijowski i doński zlodowacenia rosyjskiego, związek zatem tych owsów - i to prawdopodobnie jako tworzących własne zespoły - można uważać za wcześniejszy a sam okres zlodowacenia rosyjskiego za granicę górną pojawienia się owsa Bessera na terenie Podola.

Wiek zlodowacenia, rosyjskiego, które wytworzyło język kijowski i doński określił w swoim ezasie Kulczyński (31) jako wspólczesny polskiemu i europejskiemu L 4. Oparł się przy tym na zjawisku nieobecności we weześniejszych zlodowaceniach Polski gatunków kopalnych elementu ałtajskiego (syberyjskiego) względnie $\mathrm{N}$ azjatyckiego, jaki - jego zdaniem - powinien by się znachodzić w osadach tego okresu zlodowacenia, gdyby ono sięgało w głąb Rosji. Jednakże późniejsze badania wykazały obecność gatunków kopalnych tych elementów w weześniejszych zlodowaceniach Polski, nie tylko w osadach bezpośrednio poprzedzającego zlodowacenia Cracovien (Szafer - Ludwinów (32) Lilpop - Olszewicze (33)) ale z jeszcze dawniejszego Jaroslavien (Szafer - Hamarnia (24)). Tym samym, zgodnie z opinią autorów rosyjskich (Mirczynk, Pawłow ii. (35)) należy podnieść wiek zlodowacenia kijowskiego i uznać je za odpowiadające conajmniej okresowi Cracovien (jeśli nie Jaroslavien), zatem alpejskiemu zlodowaceniu Riss względnie środkowo-europejski€mu Saale (według autorów niemieckich np. Zeuner (37)) według rosyjskich nawet Elster (np. Żyrmunski (36) względnie Mindel (35)).

Granica zatem górna wystęowania owsa Bessera i to prawdopodobnie we własnym uformowanym zespole, wypadłaby na wezesne dyluwjum a właściwie na postpliocen (por. poniżej).

Granica dolna odpowiadaćby mogła, teoretycznie rzecz biorąc, temu okresowi geologicznemu, w którym Podole stało się ostatecznie lądem. Jako ląd wyłoniło się Podole w znacznej swojej części, z morza tortońskiego a więc w miocenie, od tego zatem okresu możnaby liczyé datę pojawienia się owsa Bessera na jego obecnych stanowiskach. Jednakże część stanowisk tego owsa a mianowicie obszar położony na wschód od linii: Złoczów, Tarnopol, przełom Zbrucza w Miodoborach był jeszcze zalanym przez mioceńskie morze sarmackie i stał się lądem dopiero w pliocenie (38). Na terenie tym, pomioceńskim, występuje owies Bessera np. na Dziewiczych skałkach i na górze Maślatyn pod Krzemieńcem, oraz na skałkach w Ostapiu i Oknie w Miodoborach. 
Wskazuje to, że jeszeze w pliocenie istnieć mogły warunki, które umożliwiły owsowi Bessera wędrówkę na terenie Podola. Że mógł to być okres w ogóle dogodny dla ruchów roślin, na to wskazuje okoliczność, że oprócz owsa Bessera występuje na tym, później, z morza sarmackiego wyłonionym lądzie, szereg roślin innych m. i. izolowanych, o silnie porozrywanych zasięgach, na co zwrócił uwagę już Szafer, wiążąc obecność pewnych z nich z istniejącym tu niegdyś wałem scytyjskim (40).

Tu ma jedyne swoje stanowisko w Polsce gatunek Helianthemum canum i podobnie rzadki Allium strictum, endemiczny Dianthus pseudoserotinus, dysjunktywne gatunki jak Schivereckia podolica, Avena Schelliana, Dracocephalum austriacum ii. (20, 40, 9, 38, 10).

Występowanie na tym terenie gatunków o pewnych cechach morfotyeznej i geografieznej starości oraz endemizmów, przy tym o zasięgach ezesściowo podobnych jak zasiąg Avena Besseri, wskazuje, że wystarezy przyjąć wiek plioceński dla tego owsa, aby uzasadnić jego izolację i endemiczność oraz fakt istnienia na terenie Podola

Jak pod tym względem przedstawiają się nasze dotychczasowe poglądy? Bliżej poświęcają temu zagadni€niu uwagę A. Kozłowska (15) i W. Gajewski (16). Kozłowska uważa Avena Besseri za jeden z najstarszych składników naszej flory i wywodzi jego pochodzenie z środkowego trzeciorzędu, wiążąc obecność jego z subtropikalnym lasem typu wschodnio-azjatyckiego.

Nadając temu owsowi charakter klimatyczny typu eurazjatyckiego, zatem łagodny śródziemnomorski względnie subtropikalny, powołuje się Kozłowska na fakt wystepowania owsa Bessera na pólnocnych zboczach gipsowych bołdów pokuckiego Podola, bardziej oceanicznych, klimatycznie wyrównanych.

Jednak pogląd tego rodzaju opiera się na niewystarczającej liczbie obserwacji oraz nadmiernym przecenieniu ogólnej wartości ekspozyeji ${ }^{1}$.

1 Gdyby nawet wehodziła w rachubę inna ekspozycja, to nie zdołałaby ona zmienić zasadniczo warunków makroklimatu kontynentalnego, w jakich żyje owies Bessera. W wyższej jeszeze mierze dotyczy to owsa Lessinga, który i ze względu na stosunki makro- jak i mikroklimatu wskazuje na jeszeze silniejsze nasilenie kontynentalizmu, w obrębie swojego zasięgu.

Podobnie nie jest uzasadnionym przypisywanie zespołom Stipa capillata wyłącznego związku z ekspozycją poludniową. Zespół ten rośnie poza wystawą południową (S, SW i SE) także przy ekspozycji zacbodniej (W, NW) oraz północnej (N, NE). Obecność zespołu na pewnym stoku może być m. i. wynikiem sukcesji np. Stipetum capillatae na Masioku k. Ostrowea rośnie na stokach północnyeh $\mathbf{w}$ sukeesji po Avenetum desertorum. Stąd nie można mechanicznie wyciągać zbyt 
Jak wynika z przeglądu stanowisk, podanego uprzednio, owies Bessera rośnie na Podolu na gifsach, wapieniach i wapnistych piaskoweach przede wszystkim przy ekspozyejach zachodnich (W, NW) rzadziej przy północnych, wschodnich i południowych, w Czechach i na Morawach na bazaltach i wapieniach, przy ekspozycji W i SE.

Owies Lessinga występuje na stepowych ezarnoziemach, pó1pustynnych glebach kasztanowatych, glinach oraz wapieniach, lupkach, granitach itp. głównie przy ekspozycji S i SE rzadziej E.

Biorąc zatem pod uwagę całokształt warunków źyciowych a więc ogólne rozmieszezenie geograficzne w strefie st€fów i fółrustyń, w tym ezęściowo górskich, warunki mikroklimatu, stworzone przez ekspozyeje głównie zachodnie i południowe, o szerszych amplitudach czynników klimatyeznych oraz stosunki podłoźa, na których występują te owsy, uznać je można za gatunki o charakterze kontynentalnym. Przy tym warunki kontynentalne, wśód jakich owsy te występują, zyskują naogół na nasileniu od zachodu ku wschodowi: od zwartego stepu turzycy niskiej Czech i Moraw do otwartych skalnostepowych zespołów owsa Bessera na Podolu a stąd do fółyustynnych asocjacji owsa Lessinga w Azji środkowej oraz w kiervnku od fódnocy ku południowi z obszaru leśnostepowego do pustynnych stepów aralsko-kasfijskich i turkiestańskich.

Stąd nawiązywanie historii owsa Bessera a tym bardziej owsa Lessinga do okresu ,bujnego subtropikaln€ go lasu, który w środkowym trzeciorzędzie... zwartym pasem okalał półkulę fółnocną“" (41), uznaé należy za zbyt mało uzasadnione.

Dla wythumaczenia obceności owsa Bessera na Podolu sięgnąc trzeba do jakiegoś okresu kontyn€ntaln€go, taki€go, który uzasadniałby raczej obecność stepu jak lasu.

Niektórzy autorzy widzą moment korzystny dla rozwoju stepów na tym terenie w wystąpieniu klimatu pustynnego (15), który według Koeppena i Wegenera charakteryzować miał zwłłaszcza wyższy miocen a obejmował m. i. Eurazję od Azji centralnej poprzez okolice ówczesnego morza śródlądowego, Polskę południową aż po południową Francje i Hiszranię $(42)^{1}$.

daleko idących wniosków ogólnych z zajmowania przez rośliny takiej czy innej wy stawy.

1 Miocen jako okres, z którego miałaby się wywodzić bezpośrednio współeześnie źyjąca flora jest i z tego względu mniej prawdopodobny, źe z miocenu i to nawet późnego jak np. torton Wieliczki znane są przeważnie współezesne rodzaje a nie gatunki. Np. na 20 gatunków znalezionych w Wieliczce wymienia Zabłocki (43) zaledwie 2 w formie kopalnej: Pinus silvestris fossilis i Fagus ferruginea fossilis, 
Jednakże obecność, jak o tym wspomniano powyżej, na pomioceńskim obszarze okolic Krzemieńca owsa Bessera z gatunkami charakterystyeznymi oraz takich roślin jak: Avena Schelliana, Stipa capillata, Stipa Joannis ii. klimatyeznie do niego zbliżonych, wykazuje, że ten okres pustynny nie był koniecznym dla wędrówek (o ile przyjmie się w ogóle jego istnienie).

Rozwój i wędrówki tego owsa mogły zatem odbywać się w warunkach klimatycznych pomioceńskich, zatem w pliocenie lub dyluwium.

Dyluwium jako główny okres rozwoju i wędrówek stepów przyjmują niektórzy autorzy rosyjscy ii. $(20,46)$ a w oparciu o nich także, z naszych, Gajewski (16).

Podobnie jak badacze rosyjscy wysuwa on jako argument okolicznośé, że w pliocenie nie było w ogóle warunków odpowiednich dla rozwoju stepów, gảyż był to okres leśny.

Przegląd kopalnych resztek roślinnych Rosji południowej wykazuje rzeczywiście, że była to przeważnie flora leśna (48) np.:

Woroneż (P. A. Nikitin):

Aserbejdżan (I. W. Palibin):

Kachetja (I. W. Palibin):

Abies, Picea, Pinus, Larix, Alnus, Cornus.

Fagus orientalis, Pulnica granatum, Salix alba, Prunus spinosa, Quercus ii.

Tilia platyphyllos, Zelkova crenata, Pirus communis, Prunus mahaleb, Acer velutinum, Ligustrum vulgare ii.

Poza tym z dyluwium, a w szezególności z okresami zlodowaceń, łączy się sprawa rozwoju stepów jako formacji towarzyszącej tundrze

przy czym są to przede wszystkim rośliny Nagonasienne, historyeznie starsze w rozwoju oraz najniższe Okrytonasienne.

A. Krysztafowicz nie przytacza na 28 gatunków Wołynia ani jednego wspóleześnie żyjącego (44).

Natomiast gatunki flory współezesnej występują pospolicie w pliocenie np. w środkowym pliocenie Krościenka według Szafera (45): Picea excelsa, Taxus baccata, Carpinus betulus, Physalis alkekengi, Ranunculus nemorosus, Cicuta virosa. Valeriana dioica.

Dla środkowego pliocenu Bułgarii wymieniają Stefanow i Jordanow gatunki jak: Larix europaea, Betula verrucosa, Sorbus aucuparia, Populus tremula, Lonicera nigra, Rhododendron ponticum, Cornus mas ii.

Stąd bardziej prawdopodobnym wydaje się przyjęcie, że w miocenie istnieć mogła ewentualnie jakaś forma wyjściowa, z której nastęnie rozwinął się owies Lessinga, $\boldsymbol{T}^{-} \mathrm{z}$ tego ostatecznie owies Bessera. 
(względnie przyarktycznym torfowiskom), związanej z nawiewaniem loessów.

Fauna stepowa, zwlaszcza ssaków, jest znaną w loessach oddawna (49), nie zachowały się natomiast wyraźne szczątki roślinne. Pewne wnioski można zatem wysnuwać tylko z resztek roślinnych zachowanych w samych osadach lodoweowych.

Ostatnio we florze towarzyszącej tundrze pod Przemyślem odkrył Kulczyński (50) nasiona halofitu ezarnomorski€go Crambe aspera, co dało Gajewskiemu okazję do uogólnienia tego odkrycia i postawienia tezy o rozwoju stepów w okresie zlodowacenia Cracovien oraz związania z tym właśnie zlodowaceniem pobytu Avena deserto rum Less. względnie Avena Besseri Griseb. na ich dzisiejszych stanowiskach.

Ponadto autorzy rosyjscy oraz Gajewski wysuwają jako dowód, świadezący o dyluwialnym wieku stanowisk owsa Lessinga względnie owsa Bessera, fakty jak: obecność Betulahumilis, a więc jak się powszechnie uważa, reliktu lodowcowego, razem z Avena desertorum na wapieniach płyty Kursko-Orelskiej, obecność rdzy Puccinia drabae, właściwej arktyeznym gatunkom Draba, na rosnącym tu gatunku charakterystycznym zespołu Avenetum desertorum, Schivereckia podolica, oraz występowanie na tym samym stanowisku innego charakterystycznego gatunku tego zespołu Chrysathemum sibiricum, spokrewnionego z arktycznym gatunkiem Chr. arcticum.

Rozpatrując powyższe argumenty stwierdzić należy co następuje:

Kopalna flora leśna Rosji południowej pochodzi bądź z młodszego pliocenu (warstwy akczygylskie i apszerońskie, uważane czasem nawet za dyluwialne) bądź ze starszego (warstwy meotyjskie np. Odessa, Tyraspol (16)) ale wówezas występuje w pobliżu fauna, której charakter nie wskazuje na warunki leśne. Np. w warstwach meotyjskich Odessy odkryto faunę strusi, antylop ii., która dowodzi współczesnego istnienia stepów.

Stąd wniosek jedynie słuszny, że na tych obszarach i w tych okresach czasu istniały warunki dopuszczające obecność stepu obok drzew a więc lasostep.

Podobny wniosek dla obszarów bardziej południowych wyciaga Kozłowska na podstawie innych danych (15) ${ }^{1}$.

1 Badacze bulgarsey Stefanow i Jordanow (39) wnioskują z nieobecności w średnim pliocenie Bułgari pewnych subtropikalnych gatunków właściwych florze Europy zachodniej (np. Ginkgo biloba, Sabal, Diospyros, Xantoxylon, Persea, 
Występowanie Betula humilis na wapieniu w towarzystwieflory stepowej świadezy o szezególnie rzadkim, z dzisiejszego punktu widzenia, ekotypie tej rośliny, zdolnym do życia na tego rodzaju stanowisku. Dało to m. i. okazje odkrywcy Litwinowowi do wyróżnienia tej rośliny jako odrębnej odmiany v. cretacea. Jitwinow przypisuje roślinie tej jednak wiek trzeciorzędowy a nie dyluwialny, uwaźając ją za relikt z tego okresu: ,ostatok... treticznoj flory pereżywszej lednikowyj period" (56).

Biorąc pod uwage fakt występowania Betula humilis w formie kopalnej w pliocenie Bułgarii (39), nie ma w tym nic nieprawdopodpodobnego.

Obecność Puccinia drabae na pewnych gatunkach rodzaju Draba (nie tyle arktyeznych co i górskich a więc circumborealnych względnie arktyezno-alpejskich) ${ }^{1}$ oraz pokrewieństwo Chrysanthemum sibiricum i Chr. arcticum wskazują na możliwość pewnych nawiązań między tymi gatunkami a florą arktyczną względnie circumborealną. Nie można jednak łączyé takich koncercji w yłącznie z zlodowaceniami dyluwialnymi, gdyż związki takie megą pochodzić z dawniejszych okresów. Zresztą nie dotyczą one ani Avena desertorum Less. ani Avena Besseri Griseb., które nie wykazują żadnych pokrewieństw w obszarze arktycznym.

Obecność nasion Crambe aspera w osadach lodowcowych pod Przemyślem nie przesądza jeszcze sama przez się sprawy stepów w okresach zlodowaceń w ogóle a w okresie Cracovien w szezególności, gdyż halofity należą do roślin, ulegających łatwo zawleczeniu na stanowiska nawet mało zbliżone do pierwotnych. Dowodem tego chéby fakt, że w tych samych osadach występuje inny halofit Blysmus rufus, mający dzisiaj odmienny charakter klimatyezny jako składnik elementu północno-atlantyckiєgo.

Bardziej przekonywujące są pod tym względem raczej dane paleozoologii jak paleobotaniki, np. badania Zeunera nad szarańezakami Staruni (53).

Zeuner odkrył w kopalnej, lodoweowej faunie Staruni gatunki zamieszkujace suche wyspy tajgi zachodniej Syberii oraz krainy stepowo-leśne jak np. Aeropus sibiricus a nawet gatunek Turkiestanu

Cinnamomum, Sapindus ii. o suszy klimatyeznej panującej podówczas na pólwyspie bałkańskim.

Koeppen i Wegener przyjmują w ogóle dla pliocenu obecność stref pustynnych w Azji centralnej i na wschodnim skraju Europy (42).

1 Poza Arktydą rosną te gatunki Draba w górach C Europy, na Kaukazie, Uralu, w górach Syberii, Kamezatki, C Azji, Anatolii i N Ameryce (56). 
Chorthippus angulatus, który prawdopodobnie zalatywał nad tundre z przyległego stepu.

Nie należy przy tym jednak zapominać, że współczesna geologia przyjmuje możliwość zlodowaceń również dla pliocenu. Zaliczane
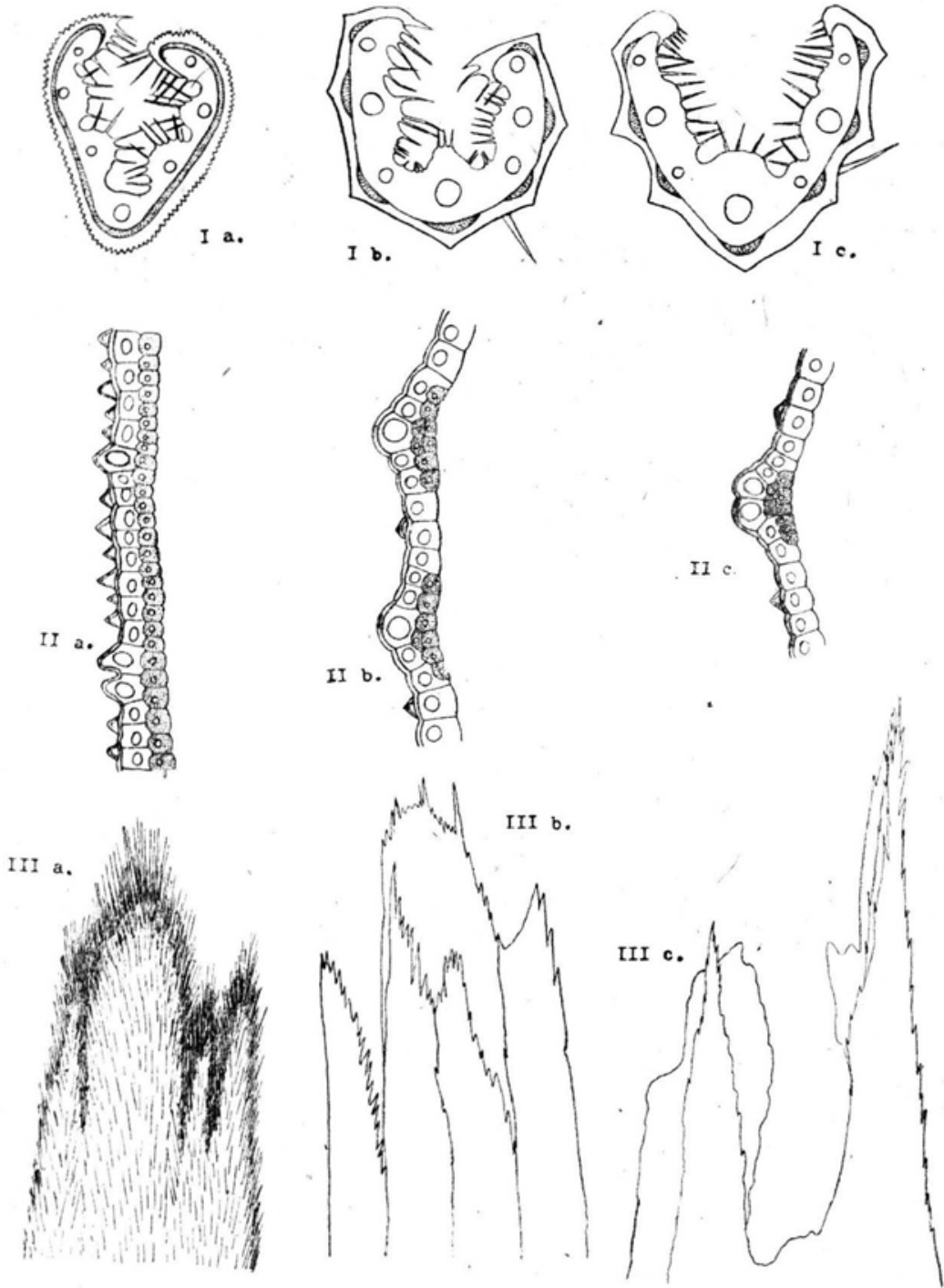

I) Przekrój przez liść: a) Avena desertorum Lessing, b) Avena Besseri Grisebach, z Podola, c) Avena Besseri Grisebach, z Czech.

II) Frágment przekroju liścia: a) Avena desertorum Lessing, b) Avena Besseri Grisebach, z Podola, c) Avena Besseri, z Czech.

III) Języczek liściowy pędu kwiatowego: a) Avena desertorum Lessing, b) Avena Besseri Grisebach, z Podola, e) Avena Beseeri Grisebach, z Czech. 
dawniej do dyluwium zlodowacenia najstarsze (Donau względnie Günz a nawet Mindel) są obecnie przydzielane do pliccenu (36, 51, 52). ${ }^{1}$ Tym samym, gdyby nawet stanąć bez wszelkich zastrzeżeń na gruncie zajmowanym przez autorów rosyjskich, znalazłoby się i w zlodowaceniach plioceńskich może miejsce dla rozwoju stepów i wędrówek roślin stepowych ${ }^{2}$.

Nie moźna jednak w sposób zbyt uproszczony ujmować tej sprawy. Step współezesny nie jest zjawiskiem jednolitym i jednorazowym. Złożony z różnych zespołów i z różnych elementów rozwijał się i wędrowal w różnych okresach geologicznych. Wśród tych zespołów jest zespół owsa Bessera niewątpliwie najstarszym na terenie Podola. Nie mniej przeto nie jest wykluczonym, że gatunek ten, zamieszkujący obecnie Czechy, Morawy i Austrię dolną, dostał się na swoje dzisiejsze stanowiska w okresie dyluwialnym (a może nawet później).

Jak świadezy przede wszystkim moment geograficzny oraz towarzystwo roślin o charakterze młodszym, jest tu owies Bessera przybyszem niewątpliwie późniejszym.

Nie narusza to jednak w niczym możliwości poważniejszego wieku stanowisk owsa tego na Podolu.

Biorąc pod uwage przytoczone powyżej momenty morfotyczne, geograficzne, ekologiczne i społeczne, można uznać iż nie ma zasadniczych przeszkód do przyjęcia, iż owies Bessera istniał na Podolu w pliocenie i przetrwal tu, jako gatunek kontynentalny, okres zlodowaceń.

Z wniosków natury ogólniejszej jakie z takiego studium monograficznego da się wciągnąé, wỳmienić można następujące:

Obszar Europy środkowej (Czechy, Morawy, Austria) pozostawał w bezpośrednim związku z Podolem i stąd otrzymywał m. i.

1 P. Beck dzieli wręcz pliocen na: praeglacjopliocen; glacjopliocen (ob jimujący zlodowacenia Donau względnie Günz oraz Mindel) i pliocen właściwy (który pokrywa się z dawniejszym interglacjałem Mindel-Riss), Zyrmunskij nazywa cały ten okres postpliocenem $(36,51)$.

20 możliwości oddziaływań przeddyluwialnyeh na zachowanie flory świadczyé może w pewnym stopniu np. stwierdzona przéz R. A. Nikitina obecność kopalnej flory leśnej (modrzew, świerk, sosna, jodła) w okolicy Syzrania (48). Sukaczéw wprowadza tę florę w związek z tym zlodowaceniem, które nie dosięgło bezpośrednio Rosji.

Biorąc pod uwagę, że w Rosji stwierdzono obecność moren odpowiadająeych zlodowaceniu Mindel (w Lichwinie), chodzi tu o któreś ze zlodowaceń poprzednich zatem $\mathrm{z}$ glacjopliocenu.

Z tajgą posuwającą się ku południowi mógł ewentualnie również przesuwać ię step przyarktyezny. 
składniki swej flory. Moźna przyjąć to zwłaszeza dla roślin o podobnym typie rozmieszczenia jak Avena Besseri, zatem, ogólnie powiedziawszy, wschodnich.

Droga wędrówki tych roślin prowadziła przez Podkarpacie, łączące w najkrótszej linii oba te ośrodki. Slad takiej łączncści rrzetrwał po dziś dzień w postaci kolonii flcry stefowej rozsianych na tym terenie (np. pod Przemyślem). Tutaj podał Kotula (57) liczna grupe roślin, właściwych dzisiaj stepom. Jedne z nich jak np. Dorycnium germanicum ii. wskazują na drogę z południa poprzez Bramę morawską, co podniósł już Szafer (58) ale inne jak np. Hieracium echioides ii. właściwe obszarom wschodnim przyszły niewątpliwie od strony Podola.

Brama morawska, która uchodzi za drogę wędrówek flory stepowej z południa na północ, była nią zatem tạkże w kierunku odwrotnym.

Panu prof. dr Wł. Szaferowi dziękuję uprzejmie za udostęrni€nie zbiorów zielnikowych i literatury, ranu dr E. Stachowi za umożliwienie przeglądnięcia zielników Akad€mii Cmiejętcści. kowie.

Z pracowni Instytutu botanieznego Uniwersytetu Jagiellońskiego w Kra-

\section{Summary}

The plant discovered by Wilibald Besser (1923) on the hills of Krzemieniec (N Podolia) and introduced as Avena Besseri Grisebach to the Flora rossica by Ledebour (1854) became later annuled as a distinct species by $\mathrm{J}$. Schmalhausen (1897) and attributed to the species Avena desertorum Lessing.

However the anatomical examination of leaves and ligula proves that there are distinct species, differing also by its geographical areas (Avena Besseri Gris. - Podolia, Avena desertorum Less. SE Russia, Sibiria, Asia).

The plant discovered later by Podpera in Bohemia (1902) Moravia (1912) (and probably the plant from Lower Austria) called Avenastrum desertorum Podp. belongs to the species Avena Besseri Griseb. (Avenastrum Besseri) Griseb.

Avena Besseri Griseb. is closest related to the species Aveno desertorum Lessing, belonging to the same section: Deserticolae Komarow (and farther related to the section: Tianschanicae Komarow) which limited to the Central Asiatic region. 
The genetic centrum of Avena Besseri Griseb. (and of one part of subgenus Avenastrum Jessen) lies thus on East and not on South (Mediterranean region).

The both species forms its own assocations and bears partly the same characteristic plants: Schivereckia podolica, Thalictrum petaloideum (Th. uncinatum) (Polygala sibirica, Allium strictum, Trifolium lupinaster) in them.

Its stations are separated by the Dniepr and Don tongues of the Russian glaciation, which geological position is determined as belonging to the Riss period.

This circumstance and the presence of common characteristic plants in both associations permits to accept that the upper limit of the appearence of Avena Besseri Gris. (probably with companions) on the Podolian plateau is connected with early diluvial period, exactly with postpliocen.

As the lower limit may be accepted the beginning of pliocen since the part of geographical area occupied at present by Avena Besseri Gris. was freed of the sea transgression at the pliocen period. On this territory are distributed many plants of isolated position and distinct disjunctions (Schivereckia podolica, Allium strictum a. oth.) or endemies (Dianthus pseudoserotinus Błocki a. oth.). The phenomenon of this kind as a larger disjunctions and endemismus may be thus explained by accepting the pliocen age. In as much as the early diluvium is at present annexed to the pliocen period (Beck P., Gams H., Girmounsky A., a. oth.) the age of Avena Besseri on the Podolian plateau may be accepted as of pliocenic range. On its actual Podolian stations Avena Besseri Gris. outlasted the periods of glaciations as a species of continental value. The stations in Bohemia, Moravia (and probably Lower Austria) may be reached at a later time (diluvium or aluvium). The actual presence of Avena Besseri Gris. in Bohemia, Moravia (and Lower Austria) is a proof that the territories of Central Europe taked its floral components directly from Podolia. The steppe flora migrated from East to C Europe through the NSubcarpatian lowland and farther through the Moravian Gate.

\section{Literatura}

(1) Besser W., Enumeratio plantarum Volhyniae, 1822.

(2) Eichwald E., Naturhistorische Skizze, 1830.

(3) Andrzejowski A., Rys botaniczny krain zwiedzonych, 1823.

(4) Ledebour C. F., Flora rossica, 1853. 
(5) Rehman A., Przegląd roślinności SKF, 1873.

(6) Schmalhausen J., Flora Rossii, 1897.

(7) Koczwara M., Przyezynek do znajomości owsów Polski, 1926.

(8) Domin K., Podpera J. Klic k uplne kvetene CSR, 1928.

(9) Koczwara M., Stosunki geobotaniczne Wołynia, 1930.

(10) Macko St., Roślinność projektowanych rezerwatów na Wołyniu, 1937.

(11) Koczwara M., Über einige interessante Avenastrum Sippen, 1926.

(12) Kulezyński St. i Motyka J., Zespoły leśne i stepowe Łysej Góry, 1936.

(13) Koczwara M., Zespoły stepowe Podola pokuckiego, 1930.

(14) Koczwara M., Step a las na Podolu pokuckim, 1945.

(15) Kozłowska A., The genetic elements and origin of the steppe flora, 1931.

(16) Gajewski W., Avenetum desertorum Less., 1934.

(17) Rehman A., Ziemie dawnej Polski, 1904.

(18) Raciborski M., Rośliny polskie, 1910.

(19) Szafer W., Geobotaniczne stosunki Miodoborów, 1910.

(20) Podpera J., Kvetena Morav, 1925.

(21) Hegi Gustav, III. Flora von Mitteleuropa,

(22) Paczoski J., Osnownyje czerty razwitja flory, 1910.

(23) Hayek G., Die Pflanzendecke Oesterreich-Ungarns, 1916.

(24) Keller B. A., Botaniczesko Geografiezeskija isledowanija, 1912.

(25) Kryłow P., Flora zapadnoj Sybiri, 1928.

(26) Sapoźnikow W. N., Szyszkin B. K., Rastitielnost zajsanskawoujezda, 1918.

(27) Sprygin J., Iz obłasti penzenskoj lesostiepy, 1925.

(28) Pawłowski Br., Elementy geograficzne i pochodzenie flory tatrzańskiej, 1929.

(29) Komarow W., Flora SSSR, 1934.

(30) Rouy, Flore de France, 1913.

(32) Szafer Wł., Die Diluvialflora von Ludwinów, 1928.

(33) Lilpop J., Interglacjał w Olszewicach, 1930.

(34) Szafer Wl., The oldest interglacial in Poland, 1932.

(35) Mirczynk G., La correlation entre les depots quaternaires, 1936.

(36) Żyrmunski A., Neue Versuche der Synchronisation, 1936.

(37) Zeuner F. E., The plejstocen ehronology of Central Europe, 1935.

(38) Koczwara M., Granice florystyczne Podola, 1925.

(39) Stefanow B. i Jordanow W., Studies upon the pliocen flora of Bulgaria, 1936.

(40) Szafer Wt., Trzeciorzędowe rośliny górskie na wale scytyjskim, 1923.

(41) Kozłowska A., Godne ochrony resztki stepów na Podolu, 1930.

(42) Koeppen W. i Wegener A., Die Klimate der Erde, 1924/40.

(43) Zabłocki J., Flora des Salzlagers von Wieliczka, 1928.

(44) Krysztafowicz A., O rastitielnych ostatkach treticznych piesezannikow, 1914.

(45) Szafer Wł., Eine pliocene Flora in Krościenko am Dunajec, 1938.

(46) Keller B. E., Rastitielnost Rossii w kartinach wg AFW Schimper i C. Faber Pflanzengeographie, 1935.

(47) Kleopow I. D., Uber das Alter der Relikte der Ukraine, 1932.

(48) Sukaczew W., Grundzüge der Entwicklung der Vegetation, 1936.

(49) Nehring W., Tundren und Steppen, 1890.

(60) Kulezyński St., Die altdiluvialen Floren der Gegend von Przemyśl, 1932. (51) Beck P., Ưber das Pliozän u. Quartär am Alpensüdrand, 1936. 
(ó2) Gams H., Die wichtigsten floristischen u. waldgeschichtlichen Unterschiede, 1935.

(53) Zeuner F. E., Das Klima des Eisvorlandes in Glazialzeiten, 1934.

(54) Schmid E., Die Reliktfoehrenwalder der Alpen, 1934.

(55) Gromow W., Ergebnisse der Forschung der quartären Säugetiere, 1936.

(56) Litwinow D. I., Betula humilis Sehr. na miełu Woroneźskoj gub. wg Wulf

E. W. Istoriczeskaja geografja rastienij, 1944.

(57) Kotula B., Spis roślin naczyniowych z okolic g. Strwiąźa, SKF 1863.

(58) Szafer Wl., Znaczenie Bramy morawskiej jko drogi migracji roślin, 1926.

(59) Gajewski W., Stosunki geobotaniczne stepu Masiok, 1932.

(60) Koczwara M., Rola ekspozyeji w geografieznym rozmieszczeniu roślin, 1925.

\section{Sprostowanie - Correction}

W ljśoie zmarłych członków Towarzystwa, zamieszczonej w pierwszym zeszycie, zostali pominięci przez niedopatrzenie - Dans la liste des membres décédés de la Société ont été omis par erreur: prof. dr Józef Przyborowski (Kraków), prof. dr Edward Ralski (Poznań), prof. dr Adam Maurizio (Bern).

Natowiast okazało się, że pozostają przy życiu — D'autre part sont retrouvés vivants: prof. Wacław Łastowski (Poznań), dr Czesława Prywer (Meksyk), Mieezyৎław Ptaszycki (Warszawa). 